\title{
DOG ASSISTED THERAPY: \\ WHEN CAN WE INDICATE TO OUR PATIENTS?
}

\section{Gabriela Monteiro de Paula}

Student of the Dentistry at Universidade Federal Fluminense, Niterói, RJ, Brazil.

\section{Maria Carolina Canadas Costa}

Student of the Post-graduation in Dental Prosthesis at the Universidade Iguaçu, Nova Iguaçu, RJ, Brazil.

\section{Bianca Santana}

Pediatric Oncology Service of the Instituto National do Câncer, Rio de Janeiro, RJ, Brazil.

\section{Marcela Dias Lopes Martins}

Pediatric Oncology Service Prontobaby Group, Rio de Janeiro, RJ, Brazil.

\section{Rodrigo Figueiredo de Brito Resende}

Oral Surgery at Universidade Federal Fluminense, Niterói, RJ, Brazil.

Institution in which the work was carried out: Universidade Federal Fluminense, Niterói, RJ, Brazil.

Gabriela Monteiro de Paula

Endereço: R. Mario Santos Braga, 30, Niterói - RJ, 24020-140

Telefone: (21) 2629-9920

REVISTA FLUMINENSE DE ODONTOLOGIA - ANO XXVIII - No 56 - Julho / Dezembro 2021 
E-mail: gabrielamonteiro013@gmail.com

\section{ABSTRACT}

Dog-assisted therapy (DAT) consists of an intervention, applied and supervised by duly qualified health professionals, in which the dog is an integral part of the treatment, causing behavioral changes and the health of people with different types of needs. This article aims to identify, through a literature review, the health areas capable of receiving intervention with dogs and their benefits in treatment. The results showed the possibility of implementing DAT in different configurations such as hospitals, nursing homes, clinics or schools and demonstrated the beneficial potential of this intervention for physical, mental and emotional rehabilitation.

Keywords: Assisted therapy; Dog; Animal.

\section{INTRODUCTION}

In the evolutionary history of man, the relationship between human beings and animals, in terms of coexistence, interaction and domestication, constituted one of the most significant events; Animals are an integral part of cultures around the world, regardless of the degree of civilization achieved. (LAMPERT, 2014) Animals arouse people's interest, attention and affection, from childhood to old age, playing an important role in their lives, whether as pets and companionship, or even as co-therapists (ALMEIDA et al ., 2016), bringing with it a strong appeal to humanization, as it helps to relax the heavy climate of a hospital environment, improves interpersonal relationships and facilitates communication (BUSSOTTI et al. 2005).

Animal Assisted Therapy (AAT) is a complementary strategy that consists of a targeted, individualized intervention with specific criteria, in which the animal is an integral part of the treatment. It must be applied and supervised by duly qualified health professionals, and can be developed with any age group and in different places: hospitals, outpatient clinics, nursing homes, rehabilitation and physiotherapy clinics or schools. (ALMEIDA et al. 2016). It is the subfield of professional activity that constitutes a process in which a professional, through animals, causes behavioral or organic changes in people with different types of needs. (GARCIA and BATOMÉ, 2008). All types of animals are used that can come into contact with humans without offering them danger, the main animal being the dog, as it has a natural affection for people, is easily trained 
and capable of creating positive responses to touch, having great acceptance by people. Animal therapy achieves more efficient results with animals that can be touched. (KAWAKAMI and NAKANO, 2002).

Dog Assisted Therapy (DAT) has shown over the years to be a very useful and effective approach for the improvement of the individual with different pathologies and has enabled people to make several changes that are involved in their biopsychosocial development. (BUNDUKI and MILANEZ, 2015). The dog is the animal of choice to promote relaxation and distraction in health treatments and in education, as they are capable of generating a feeling of security in the patient. (VICENT et al. 2020)

\section{LITERATURE REVIEW}

MACHADO et al. (2008) state that Animal Assisted Therapy (AAT) can be applied in areas related to psychomotor and sensory development, in the treatment of physical, mental and emotional disorders, for programs aimed at improving the ability to socialize or recovering self-esteem. Likewise, BUNDUKI and MILANEZ (2015) mention that AAT has clear and directed objectives, where the interaction between man and animal can generate benefits such as: well-being, removal from the state of pain, encouragement of physical / speech functions, decreased anxiety and stress, reduced blood pressure, reduced heart rate, stimuli to memory, stimulus to cognition and socialization.

For ALTHAUSEN (2006) and LUNDQVIST et al. (2017), the canine species have characteristics that facilitate the formation of a bond with the human being because they are good observers of human reactions through their exceptional ability to read signs of desires and emotions on human faces, also presenting a behavior that individuals interpret as happy, friendly and affectionate, which makes them suitable for use in interventions with a therapeutic purpose.

KAWAKAMI and NAKANO (2002) pay attention to the fact that the inclusion of the dog in the therapy program requires the performance of a set of tests to guarantee the animal's full health. They must behave well, react in a sociable way to strangers and 
be used to other animals; small and large dogs of any breed can participate, as long as they obey basic obedience commands. VACCARI and ALMEIDA (2007) reinforce that all animals used in these programs must pass the evaluation of professionals in the area of veterinary and behavioral psychology, they must be evaluated, reassessed and monitored.

MANDRÁ et al. (2019) demonstrated, through a literature review with 43 articles published between 2010 and 2018, that the dog is the most mentioned animal in the AAT programs, being chosen for different therapeutic purposes (Table 1).

SANTOS and SILVA (2016) presented a survey that identified existing AAT projects in the state of São Paulo. With the results obtained, it was possible to analyze the dog breeds most used in the projects found, with Golden Retrivier dogs being the most prominent as a co-therapist (Table 2). It is mentioned that this fact can be explained by the calm behavior and the quick sociability that this breed presents, having a pleasant temperament when in contact with children and the elderly. In addition, it was also observed that most projects followed the goal of biopsychosocial development.

Table 1: Therapeutic purposes attributed to the use of the dog as a co-therapist.

\begin{tabular}{|c|c|c|}
\hline $\begin{array}{c}\text { Diagnosis } \\
\text { of the patient }\end{array}$ & $\begin{array}{l}\text { Finalty } \\
\text { Therapy }\end{array}$ & $\begin{array}{c}\text { Animal } \\
\text { Mediator } \\
\text { More used }\end{array}$ \\
\hline $\begin{array}{l}\text { Locomotor impairment, chronic pain and acute pain } \\
\text { associated with different pathologies, hypertension, } \\
\text { type } 2 \text { diabetes, obesity, cerebral palsy, acute } \\
\text { psychiatric disorders, stress, anxiety and depression, } \\
\text { cancer, physical and mental deficiencies, surgical } \\
\text { procedures and immediate postoperative period, } \\
\text { elderly patients apparently healthy and learning } \\
\text { difficulties }\end{array}$ & Physics & $\begin{array}{c}\text { Dog } \\
\text { (33 works) }\end{array}$ \\
\hline $\begin{array}{l}\text { Mental illnesses, Psychotic disorders, Alzheimer's } \\
\text { disease, Delay in the learning process }\end{array}$ & Cognitive & $\begin{array}{l}\text { Dog } \\
(8 \text { works })\end{array}$ \\
\hline $\begin{array}{l}\text { Stroke, Delay in the learning process, Depression } \\
\text { and anxiety, Developmental dysphasia }\end{array}$ & $\begin{array}{l}\text { Communicati } \\
\text { on }\end{array}$ & $\begin{array}{c}\text { Dog } \\
(4 \text { works })\end{array}$ \\
\hline
\end{tabular}


Cancer, fibromyalgia $\quad$ Emotional (3 works)

Source: Adapted from Mandrá et al. (2019)

Table 2: Dog breeds most used in projects in the State of São Paulo.

\begin{tabular}{cc}
\hline Breed & Number of dogs \\
\hline Golden Retrivier & 11 \\
Labrador Retrivier & 4 \\
Yorkshire & 3 \\
Lhasa Apso, Poodle, Shitzu, \\
Terra Nova, Cocker Spaniel \\
Beagle, Border Collie, Pastor de \\
Shetland, \\
West, Sheepdog, Old English, \\
Boiadeiro Bernes, Samoieda
\end{tabular}

Source: Adapted from Santos e Silva (2016)

KOBAYASHI et al. (2009) report that AAT sessions with hospitalized dogs and children facilitated socialization and distraction during painful procedures. Other reports show that the interaction between dog and patient improves the cardiovascular pattern by decreasing blood pressure and cholesterol levels. In addition, this interaction also increases the plasma concentration of â-endorphins, cytokines, prolactin, dopamine and decreases the plasma concentration of cortisol, generating results that act positively in the state of anxiety. ELMACI and CEVIZCI (2015) also admit that this relationship can be beneficial to improve agitated behavior and the psychological symptoms of chronic diseases that involve physical and mental disabilities.

CHUBAK et al. (2017) conducted an assessment on the feasibility of animal activities for pediatric oncology patients admitted to Seattle Children's Hospital, in the city of Seattle. Preliminary data were collected on the potential benefits for this group, the results were summarized according to the average changes in suffering pre and post intervention, verifying the following variables: less distress and significant decrease in worry, tiredness, fear, sadness and pain after the visit of the therapy dog. Patients and parents were always or almost always anxious to see the dog, they smiled, they seemed more relaxed and the patients were excited. In addition, when answering the question REVISTA FLUMINENSE DE ODONTOLOGIA - ANO XXVIII - No 56 - Julho / Dezembro 2021 
"Did you enjoy being visited by the dog?" no patient reported not having enjoyed the visit.

YAMAMOTO et al. (2012) presented a study carried out with a behavioral observation of nine dogs from the project Cão-Cidadão-Unesp through the analysis of serum and salivary cortisol levels, parametric evaluation and observation of behavioral changes at certain times. The results showed that animal-assisted therapy does not seem to cause significant stress to dogs, as it does not directly interfere with animal welfare and health. Neither was negative stress behavior observed, concluding that AAT is capable of causing benefits to humans without harming the animal.

\section{IN THE DENTAL CLINIC}

GUSSGARD et al. (2019) mention that most human beings are capable of handling dental consultations well, but for people who suffer from odontophobia, it may not be so easy. The dental therapy dog can help reduce stress, anxiety and also act as a communication icebreaker for an anxious patient to talk about their distress in dental care. And they also emphasize that, for this type of therapy, the dog must be used to the environment of a dental examination and, thus, be able to demonstrate to the patient that there is nothing to worry about. The authors exemplify that when the dental therapy dog shows comfort and tranquility in the dental chair, the child may want to try the same.

VICENT et al. (2020) state that the interaction of the pediatric patient with an animal can reduce anxiety and fear in dental care and this therapeutic modality can reduce the use of benzodiazepines to control the behavior of these patients. They conducted a study in which they assessed the acceptance and demand of those responsible for children who are candidates for Therapy Assisted by Dogs and of the dental and auxiliary professionals responsible for the care of children, through a questionnaire for these two groups. The results of the research show that the use of dogs in the waiting room was approved by more than $80 \%$ of the guardians of children, while in the treatment room it was a little more than $60 \%$. However, there is still concern among parents, because, although the dog is a novelty and distraction for the child, it can also bring both positive effects, such as drawing your attention to the dentist, and negative effects, not allowing the child listens to the dentist; in addition, there was a tendency to concern about cleaning 
COPYRIGHT @ 2021 INTERNATIONAL JOURNAL OF SCIENCE DENTISTRY | AVAILABLE ONLINE http://www.periodicos.uff.br/index

the environment, training and temperament of the dog and allergies. With oral health professionals, $31 \%$ approved, 54\% said they were neutral and $11.5 \%$ made negative comments regarding therapy with dogs in the waiting room; while in the treatment room, $16 \%$ were positive, $46 \%$ neutral, $33 \%$ negative. Seen like this, the dental health team showed concern about the risk of accident, infection control and clinical effectiveness.

\section{DISCUSSION}

The interaction between man and animal goes back to the beginnings of human relations and demonstrates, through countless records, that these bonds of affection between human beings and animals are capable of providing well-being in different perspectives throughout life. Based on these potential benefits, AAT brings the possibility of helping traditional therapies making the process less traumatic and more pleasant for patients with different health conditions and with different ages. (LAMPERT, 2014; ALMEIDA et al., 2016; GARCIA and BATOMÉ, 2008).

To be chosen as a co-therapist, animals must have the ability to maintain satisfactory and friendly contact with humans. Among all the available options, the dog appears as the animal of preference due to its good levels of obedience and its good interaction with patients, being able to trigger significant improvements in biopsychosocial development regarding physiological functions, daily well-being and encouragement to proceed with basic therapies. (KAWAKAMI and NAKANO, 2002; BUNDUKI and MILANEZ, 2015).

The use of the dog is the interaction most mentioned by the AAT projects, being included for different therapeutic purposes such as physical, cognitive, emotional rehabilitation and stimulating communication in patients with the most varied diagnoses. Records are also found for other benefits such as: improvement in the cardiovascular pattern, improvement in the state of anxiety and stress, improvement in the behavior and psychological symptoms of chronic diseases, decrease in fear or sadness and possibility of distraction during painful procedures. (MANDRÁ et al. 2019; KOBAYASHI et al. 2009; ELMACI and CEVIZCI, 2015; CHUBAK et al. 2017). 
In addition to presenting extremely favorable behavioral characteristics for their inclusion in these programs, dogs also receive good acceptance from patients for the role of co-therapist. However, in order to build a beneficial relationship without harming the animal's health, it is necessary to follow a routine of evaluation and monitoring through examinations and veterinary monitoring. (ALTHAUSEN, 2006; LUNDQVIST et al. 2017; KAWAKAMI and NAKANO, 2002; YAMAMOTO et al. 2012).

In dental practice, the participation of therapy dogs plays an important role in improving the consultation environment for both children and adults, in addition to bringing the possibility of reducing the use of benzodiazepines. The reduction of stress and anxiety, improved communication, increased safety and relaxation of patients with conditions of distress to care are some of the benefits that can be generated. (GUSSGARD et al. 2019; VICENT et al. 2020).

\section{FINAL CONSIDERATIONS}

The animal can be an aid in human biopsychosocial development and act as a cotherapist for various diagnoses, from physical to emotional. Thus, the dog is the animal most used in animal-assisted therapies, since it has excellent behavioral characteristics and acceptance by the patient.

According to the studies, it is concluded that, with the Assisted Therapy by Dogs, the general health of the patient is benefited and the therapeutic procedures are facilitated, being even dispensed, or minimized, the use of medications to control anxiety during the procedures. It is observed that, in addition to controlling the patient's health, the dog must also have periodic veterinary monitoring. 


\section{REFERENCES}

1. LAMPERT, Manoela. Benefícios da relação homem-animal. 2014. Trabalho de conclusão de curso (Graduação em medicina veterinária) - Universidade Federal do Rio Grande do Sul, 2014.

2. ALMEIDA F.A.; DONASCIMENTO A.A.;DUARTE A.M. Terapia Assistida por Animais: A Experiência dos Enfermeiros com o Uso Desta Prática em um Hospital Oncológico. Atas - Investigação Qualitativa em Saúde. v. 2 (2016):

3. BUSSOTTI, E.A; LEAO, E.R.; CHIMENTAO, D.M.N.; SILVA, C.P.R.. Assistência individualizada: posso trazer meu cachorro? Rev. esc. enferm. USP [online]. 2005, vol.39, n.2, pp.195-201.

4. GARCIA, M. P.; BATOMÉ, S. P. Da Domesticação à Terapia: o Uso de Animais para Fins Terapêuticos. Interação em Psicologia, 2008, 12(1), p. 165-167

5. KAWAKAMI, C. H.; NAKANO, C. K. Relato de experiência: terapia assistida por animais (TAA) - mais um recurso na comunicação entre paciente e enfermeiro. Simpósio brasileiro de comunicação em enfermagem, 8, 2002, São Paulo. Escola de Enfermagem de Ribeirão Preto - USP, 2002. Disponível em: <http://www.proceedings.scielo.br/scielo.php?script=sci_arttext\&pid=MSC0000 000052002000100009\&lng=en\&nrm=abn>. Acesso em: 23 Jun. 2020.

6. $8^{\circ}$ Congresso de Extensão Universitária da UNESP, 2015. TERAPIA ASSISTIDA POR CÃES NA APRENDIZAGEM DE ADOLESCENTES COM DEFICIÊNCIA INTELECTUAL, Bunduki, T. O.; Milanez, S. G. C.

7. VINCENT, A.; EASTON, S.; STERMAN, J.; FARKAS, K.; HEIMA, M.. Acceptability and Demand of Therapy Dog Support Among Oral Health Care Providers and Caregivers of Pediatric Patients. Pediatr Dent. 2020;42(1):16-21.

8. MACHADO, J. A. C.; ROCHA, J. R. SANTOS, L.M.; PICCININ. A. Terapia assistida por animais (TAA). Revista Científica Eletrônica de Medicina Veterinária, ed. 10, 2008.

9. ALTHAUSEN, Sabine. Adolescentes com síndrome de Down e cães: compreensão e possibilidades de intervenção. 2006. Dissertação (Mestrado em Psicologia Escolar e do Desenvolvimento Humano) - Instituto de Psicologia, Universidade de São Paulo, São Paulo, 2006. doi:10.11606/D.47.2006.tde13092006-154744. Acesso em: 2020-06-23. 
10. LUNDQVIST, M.; CARLSSON, P.; SJÖDAHL, R.; THEODORSSON, E.; LEVIN, L-Å.. Patient benefit of dog-assisted interventions in health care: a systematic review. BMC Complementary and Alternative Medicine (2017) $17: 358$

11. VACCARI, AMH; ALMEIDA, FA. A importância da visita de animais de estimação na recuperação de crianças hospitalizadas. Einstein. 2007; 5(2):111116

12. MANDRÁ, P.P.; MORETTI, T.C.F.; AVEZUM, L.A;KUROISHI, R.C.S. Animal assisted therapy: systematic review of literature. CoDAS 2019;31(3).

13. SANTOS, A. R. O; SILVA, C. J. Os projetos de terapia assistida por animais no estado de São Paulo. Rev. SBPH vol.19 no. 1, Rio de Janeiro - Jan./Jul. - 2016

14. KOBAYASHI, C. T. et al. Desenvolvimento e implantação de Terapia Assistida por Animais em hospital universitário. Rev Bras Enferm, Brasília 2009 jul-ago; 62(4): 632-6

15. ELMACI, D. T.; CEVIZCI, S. Dog-Assisted Therapies and Activities in Rehabilitation of Children with Cerebral Palsy and Physical and Mental Disabilities. Int. J. Environ. Res. Public Health 2015, 12, 5046-5060.

16. CHUBAK, J.; HAWKES, R.; DUDZIK, C.; et al. Pilot Study of Therapy Dog Visits for Inpatient Youth With Cancer. J Pediatr Oncol Nurs. 2017;34(5):331341. doi:10.1177/1043454217712983

17. YAMAMOTO, K. C. M., et al. Avaliação fisiológica e comportamental de cães utilizados em terapia assistida por animais (TAA). Arq. Bras. Med. Vet. Zootec., v.64, n.3, p.568-576, 2012

18. GUSSGARD, A.M.; WEESE, J.S.; HENSTEN, A.; JOKSTAD, A.. Dog-assisted therapy in the dental clinic: Part A-Hazards and assessment of potential risks to the health and safety of humans. Clin Exp Dent Res. 2019;5(6):692-700. 